\title{
Can Environmental Regulations Drive Intemational Trade? Lessons for Asia from the European Union's Performance of Buildings Directive
}

\author{
Matthias Helble1, Adam Majoe ${ }^{2+}$ \\ ${ }^{1}$ Asian Development Bank, Philippines \\ ${ }^{2}$ Waseda University, Japan
}

\begin{abstract}
International trade is one of the key mechanisms for the diffusion of energy-efficient technologies. Yet, little is known about how environmental regulations, such as those aimed at increasing energy efficiency, affect international trade in environmental or green goods. This paper studies the case of the Energy Performance of Buildings Directive, which was adopted in 2010 by the European Union. We use pooled ordinary least square and Poisson estimators to empirically test whether and how differences in implementation affected trade in relevant products. We find strong evidence that those EU member states that implemented the directive to a large extent had substantially higher import volumes of environmental products at possibly lower prices. For certain environmental products, exports equally increased. Our paper is the first to show that the implementation of environmental regulation can spur international trade in environmental products. These findings can provide important lessons for Asia and help transform it into a more competitive, prosperous, and greener region.
\end{abstract}

Keywords: EU Energy Performance of Buildings Directive, Asia, International Trade, Energy-Efficient Technologies, Non-market Instruments

\section{Introduction}

International trade is a key driver behind the diffusion of energy-efficient technologies. Yet, research is relatively lacking when it comes to how environmental regulations, such as those designed to increase energy efficiency, affect international trade in environmental or green goods. This paper examines the trade effect of the Energy Performance of Buildings Directive (EPBD), which was adopted in 2010 at the European level and transposed into national law by European

\footnotetext{
+Corresponding Author: Adam Majoe

PhD Candidate, Waseda University, Nishi-Waseda Bldg. 7F, 1-21-1 Nishi-Waseda, Shinjuku-ku, Tokyo, Japan, Tel: +81 804110 2087, Email: amajoe@moegi.waseda.jp

Co-Author: Matthias Helble

Economist, Asian Development Bank, 6 ADB Avenue, Mandaluyong City, 1550, Metro Manila, Philippines, Tel: +63

2683 1120, Email: mhelble@adb.org
} 
Union (EU) member states. The directive is a prime example of regional cooperation for the promotion of low-carbon technologies based on non-market instruments.

The member states differed in their effective implementation of the directive-thus, we have the case of a policy change applied to a group of countries and implementation that varies across countries. The objective of this study is to examine how different degrees of implementation of new environmental regulations affect trade. Building this information into a gravity model, we empirically test whether and how differences in implementation affected trade in relevant products. The findings show that strong implementation of the EPBD following its introduction and transposition for EU member states is associated with higher import volumes of environmental products at lower prices. This suggests that the EPBD indeed had a profound impact on the EU market for energy consumption and energy-related products. Our paper is the first to show that the implementation of environmental regulation can spur international trade in environmental products.

Our empirical analysis highlights the potential for regional policies to promote trade in low-carbon and energy-efficient products using the example of the EU directive. This has important implications for the relationship between trade and regional policies for energy-efficient goods that can be applied to other regions. While Asia continues on its path of increased economic prosperity, collaborating on technical regulations in the area of environmental protection could be an enormous, yet underestimated, chance to transform Asia into a more competitive, prosperous, and greener region, showing the importance of the process of economic integration.

The paper is structured as follows. Following a descriptive background, we present the main features and the design of the EPBD and a review of the existing literature. We then introduce the data and methodology used for the empirical analysis. Finally, we present and discuss the results, followed by a discussion of the implications of the findings for Asia and the Pacific and some concluding remarks.

\section{Non-Market Instruments to Promote the Use of Low-Carbon Technologies}

\section{A. Background}

Policy instruments can be divided into two groups. First are measures that directly target the price of energy, energy-related products, or emissions. For example, the Directive on Emissions Trading (EU 2009a) established a market for carbon trading and therefore works with a price mechanism. Second are measures that change the production or consumption patterns by introducing new regulations and/or technical standards. For example, the Ecodesign 
Directive (EU 2009b) set minimum standards for energy efficiency of certain energy-using products, such as household appliances and lighting-related products. Both types of instruments have the potential to alter trade flows. The trade effect of price-based instruments on trade is straightforward. The policy intervention alters the prices of goods, thereby triggering a change in demand. In another example, EU member countries typically promote renewable energy by subsidizing renewable technologies, such as solar (photovoltaic) panels or wind turbines. One of the most commonly used tools is feed-in tariffs. These subsidies lowered the prices of these technologies, thus inducing new demand. This also meant increased imports of low-carbon technologies.

Among the numerous legislative acts, this paper focuses on the EPBD, a directive aimed at increasing the energy efficiency of buildings. It works through technical standards and regulation and, therefore, differs from directives that directly intervene in the price setting of markets. Unlike for market instruments, the trade effect on non-market instruments to promote the diffusion of energy-saving technologies is still unknown. This paper aims to fill this gap.

The advantage of our research set-up is that the same regulation was introduced in all EU member states-the only difference was the speed of its implementation. In other words, the European Commission decreed new legislation in 2010, and all 28 EU member states had until 2012 to transpose the legislation into their national laws. Interestingly, implementation speeds varied substantially, and the implementation gaps have been quantified in a study by Ecofys (2015). As an important contribution, we can test whether the progress in implementing the same environmental regulation across all EU member states had an impact on the trade flows of particular goods.

\section{B. The energy performance of buildings directive}

Buildings currently account for about $40 \%$ of the EU's total energy consumption, and the number of buildings in the EU continues to increase (Odyssey-Mure 2015). Targeting the energy consumption of buildings has thus become a key element in the implementation of the European Strategy for Energy and Climate Change. The EPBD (EU 2010) was introduced in 2010 as a successor to a previous version of the directive that was enacted in 2002 to achieve the EU's goals under the Kyoto Protocol (European Parliament 2002). The 2010 directive made several important changes to consider recent changes, trends, and practices in the buildings industry.

The EPBD establishes a legally binding framework for managing the energy performance of buildings. It aims to increase energy efficiency and promote practices for reducing energy consumption. At the same time, it aims to not interfere in the key attributes of buildings, such as accessibility, safety, and intended use. EU member states were given until 9 July 2012 to fully transpose the EPBD into their national laws. The member states were solely responsible 
for implementing the directive and had to periodically report on their progress to the European Commission. In return, the role of the European Commission was to provide further guidance and recommendations and monitor the overall progress toward the objectives of the directive. In this context, the European Commission commissioned a report by the consultancy Ecofys to evaluate the gap between the EPBD and the actual implementation by the member states. The report was published in 2015 and revealed substantive gaps in terms of the implementation of the directive.

\section{Main features of the directive}

The EPBD requires the EU member states to determine the minimum energy performance requirements for buildings at cost-optimal levels. These requirements vary depending on whether buildings are new or existing and their category of use. New buildings must meet, where possible, the determined minimum energy performance requirements and use energy-efficient systems. Specific suggestions for the types of systems to be used include energy supply systems from renewable sources, cogeneration systems, district or block heating and cooling, and heat pumps. For existing buildings, when major renovations are carried out, the renovated parts or the whole building should be upgraded to meet the minimum energy performance requirements.

Another key feature of the directive is achieving nearly zero-energy buildings (NZEBs), which are defined as buildings that have very high energy performance and require nearly zero or only minimal amounts of energy that should come primarily from renewable energy sources. The inclusion of the NZEBs is designed to address the need for more buildings that not only meet minimum energy performance requirements but are also more energy efficient and can, therefore, achieve lower energy consumption and carbon dioxide emissions. This target is one of the most challenging parts of the directive.

The next important requirement of the directive obliges member states to establish systems for issuing energy performance certificates for buildings, as well as reference indicators through which owners and tenants may easily assess the energy performance of buildings. Recommendations are included in the energy performance certificates and are important for providing viable ways of improving a building's energy efficiency. Recommended measures may include increasing loft insulation, improving cavity wall insulation, installing low energy lighting for fixed outlets, and using solar water heating.

\section{Trade Effects and Existing Literature}

Technical standards and regulations can work their way into trade patterns through two 
channels. The first one, called the "pollution haven" hypothesis, suggests that stricter environmental regulation will drive emission-intensive industries toward countries with less stringent environmental regulations. Consequently, trade in products from polluting industries, such as non-ferrous metals or paper, will increase. A solid body of empirical trade literature has tried to test the "pollution haven" hypothesis, with mixed results thus far. For example, Janicke et al. (1997) do not uncover any empirical evidence of the respective changes in trade patterns. However, other studies, e.g., Cole and Elliott (2003), Cole et al. (2014), and Jug and Mirza (2005), do find trade patterns that are consistent with the pollution haven hypothesis.1)

A contrasting theory is the Porter Hypothesis, which was first proposed in the early 1990s (Porter and van der Linde 1995). The Porter Hypothesis proposes a relationship between trade and environment through effects on productivity and efficiency-that is, that environmental policies improve incentives for innovation. This is because individuals or firms may be risk averse, myopic, or otherwise unable to realize profitable investment opportunities. As such, environmental regulation may induce investment that becomes profitable ex-post. This can lead to a win-win situation where appropriately designed environmental regulation instruments can improve efficiency and product value, thus creating demand for environmental goods that can save energy and prevent or abate pollution (Jaffe and Palmer 1997).

To test the Porter Hypothesis, Wang, Zhang, and Zeng (2016) examine the impact of environmental regulations on international trade for the Chinese economy using trade data for the period 1985-2010. They find that generally, in most sectors, stricter environmental regulation reduced trade in primary (pollution-intensive) products and encouraged trade in high value-added green products. They suggest this could be the result of stringent regulations encouraging firms to provide green and environmental products.

Similarly, Costantini and Mazzanti (2012) use energy and environmental taxation in the EU as a proxy for environmental regulation and $R \& D$ patents for innovation. They examine the effect of environmental regulations and innovation on export competitiveness in the EU. Their findings show strong evidence that environmental policy actions promote export dynamics rather than undermine EU competitiveness in international markets, suggesting support for the Porter Hypothesis.

While the previous literature offers important insights, it generally employs broad definitions of environmental regulation or energy efficiency. Standards and technical regulations usually have a more direct trade effect. Typically, the research question of how new environmental standards impact trade is studied case-by-case because regulations differ from country to country. If a country introduces new environmental standards, they will most likely trigger a stronger

1) Another strand of literature studies environmental regulations' impact on other economic dimensions, such as competitiveness and employment. A recent meta-study by Dechezlepretre and Sato (2014) provides a good overview of the state of the extant literature. They show that the existing empirical literature has shown evidence of both positive and negative effects of environmental regulations on competitiveness and employment. 
demand for certain products. This increase in demand can be satisfied by domestic producers and/or imports. In the end, one could probably observe an increase in imports of the respective products. However, the evidence would then be limited to observe an increase and, most likely, fall in certain products. The insights gained from such a study would therefore be small as the environmental policies and implementation differ by country.

Most previous research ignores the fact that environmental regulation can also impact trade in products that help to comply with tighter environmental standards. These products can either be new low-carbon technologies, such as solar panels, or standard products that can be used to save energy, such as insulation materials. Whether the trade impact is positive or negative depends on the design of the environmental regulation. According to the WTO's Agreement on Technical Barriers to Trade, new technical regulations and standards should follow international standards and allow for mutual recognition and assessment results. The intention is to avoid that new environmental standards create unnecessary obstacles to international trade.

One interesting example is energy-efficiency labels. A number of countries have introduced energy-efficiency labels. This trend started in developed countries, but today a considerable number of developing countries also use them (UNEP and WTO, 2009). The labeling schemes are sometimes voluntary, sometimes mandatory. Shen and Saijo (2009) examine the changes in consumer purchasing decisions related to the China Energy-Efficiency Label. They find that appliances with energy efficiency labeling are preferred by consumers because they provide more information. They also find that customers are more willing to pay for energy efficiency appliances that they use frequently. Meanwhile, Sammer and Wustenhagen (2006) analyze the influence of EU energy labeling on consumers' purchasing of household appliances in Switzerland. They find a high level of awareness of the labeling system and show that consumers are willing to pay a price premium for highly rated appliances. Unfortunately, few energy-efficiency labels are identical across countries, which introduces additional costs for producers and ultimately consumers. Finally, Han et al. (2018) study the question of whether trade integration helps countries to catch up in terms of energy efficiency. Using a sample of 89 countries between 2000 and 2014, the authors find that trade integration had a positive influence on convergence across the countries, especially among middle- and low-income countries.

To our best knowledge, there have been no previous studies specifically examining the effect of the speed of policy implementation on trade in related environmental goods. The closest have been studies assessing the harmonization of standards and their trade effects. Grajek (2004), for example, assesses the relationship between the adoption of ISO 9000 standards, which include technical, environmental, and management standards as well as bilateral trade. The study estimates a gravity equation using data on 101 countries for the period 1995-2001. In general, the study finds that the adoption of the standards had a significant and positive effect on international trade. In contrast with this study, we analyze not a private standard but the impact 
of national legislation.

Another new element of our research is that we use a new measure of the actual implementation of environmental regulation. Existing studies, such as Cole and Elliott (2003), use rather crude measures of the current level of environmental regulation, without including aspects of actual implementation. Thus, our study is the first to examine the impact of different speeds of implementation of environmental regulation on trade.

\section{Implementation of the Directive}

Ecofys (2015) collected data on the gaps in the implementation of the EPBD from reports submitted to the commission by the member states. They collated statistics of the current minimum energy performance requirements of each member state and compared them to the cost-optimal levels. In other words, they calculated the difference between the current legally binding levels of energy efficiency in each member state and the levels required by the EPBD.

Overall, they evaluated the gaps in 10 categories: new construction of (1) single-family buildings, (2) multi-family buildings, and (3) non-residential buildings; major renovations of (4) single-family buildings, (5) multi-family buildings, and (6) non-residential buildings; and, finally, renovations at the elemental level for (7) walls, (8) roofs, (9) windows, and (10) floors.

All EU member states except for Greece and the Netherlands submitted reports to the commission. The reports do not all cover all 10 categories, and, therefore, Ecofys was unable to include some countries in the corresponding rankings. If we had included only the member states for which data in all categories are available, the sample would be reduced to 12 countries. In order to avoid such a sharp drop in sample size, we calculated the weighted average across all categories, adjusting for the number of categories for which data are available. Applying this approach, we were able to form a rating for each member state (except for Greece and the Netherlands), reflecting strong or weak performance with regards to implementation. The results of our calculations are listed in Table 1. A low implementation score indicates the member state achieved a high level of implementation. Conversely, a higher score indicates a weak implementer.

In order to have an alternative measurement for the degree of implementation, we develop an ordinal ranking based on the Ecofys (2015) data. In order to do so, we first rank the EU member countries based on their performance across the following categories: performance in implementation with respect to new constructions, major renovations, and building elements for single-family buildings, multi-family buildings, and non-residential buildings. Using these category-specific rankings based on the implementation of the directive, we assigned and aggregated simple descending scores based on the ranking orders and used these to construct 
76 Journal of Economic Integration Vol. 35, No. 1

an implementation index based on the rankings. These are shown in Table 1 as the implementation rank scores.

Table 1. Implementation scores by country

\begin{tabular}{|c|c|c|}
\hline Country & Implementation Gap Score & Implementation Rank Score \\
\hline Austria & 40.6 & 7.3 \\
\hline Belgium & 31.6 & 6.7 \\
\hline Bulgaria & 5.3 & 8.7 \\
\hline Croatia & 53.0 & 8.4 \\
\hline Cyprus & 25.2 & 15.0 \\
\hline Czech Republic & 0.0 & 12.2 \\
\hline Denmark & -2.0 & 14.0 \\
\hline Estonia & 0.5 & 14.8 \\
\hline Finland & 7.1 & 12.5 \\
\hline France & 1.2 & 14.5 \\
\hline Germany & 0.0 & 14.4 \\
\hline Hungary & 38.9 & 6.5 \\
\hline Ireland & 43.9 & 7.3 \\
\hline Italy & 18.7 & 10.9 \\
\hline Latvia & 33.9 & 7.7 \\
\hline Lithuania & 49.2 & 5.5 \\
\hline Luxembourg & 10.0 & 11.1 \\
\hline Malta & 57.8 & 5.7 \\
\hline Poland & 49.4 & 5.0 \\
\hline Portugal & -6.0 & 12.2 \\
\hline Romania & 24.8 & 8.3 \\
\hline Slovakia & 59.3 & 4.4 \\
\hline Slovenia & 9.0 & 10.8 \\
\hline Spain & -11.8 & 14.7 \\
\hline Sweden & 5.6 & 12.6 \\
\hline United Kingdom & -18.8 & 20.3 \\
\hline
\end{tabular}

(Note) The ranking valuation was scored based on the Ecofys (2015) rankings by evaluation category for each EU Member State.

(Source) Authors.

\section{Empirical Analysis}

The EPBD has the objective of substantially lowering energy consumption in the EU. Although all EU members were required to transpose the directive into national law by 2012, the speed of implementation differed among the member states. Ecofys (2015) was tasked with 
evaluating the implementation progress of the directive. Their report shows that progress varied substantially across EU member states depending on the type of building and the measure used.

The differences in implementation speed allow us to study an interesting situation. In theory, the implemented EU legislation should have had a direct impact on the product markets of member states, including international trade. Products required for energy efficiency savings, either directly through lower energy consumption or indirectly through helping to save energy, should have experienced a growth in demand. The demand, in turn, should have been satisfied through higher domestic production or imports.

If all EU member states had implemented at the same speed and made all adjustments by January 2013, then we could expect to see an increase in demand for the products before and shortly after the implementation. This would translate into higher imports from within and outside of the EU. In the medium run, international trade would probably have stabilized at a higher level as the more energy-efficient technologies faced lasting higher demand. However, in the long run, new technologies might have replaced the older products, leading to a fall in trade.

This case, however, remains hypothetical because the member states implemented at different speeds. The research question is, therefore, different and maybe even more interesting: Do differences in implementation speed have an impact on the trade performance of EU member states? In other words, does slower implementation result in lower imports of energy efficient-technology?

In order to identify the trade effect described above, we need to study trade in specific products that can be directly linked to the adoption of energy-efficiency targets. Products that fulfill the requirements of other EU directives, such as the ecodesign or energy efficiency labeling requirements, are less interesting to analyze because although these regulations are mandatory, they do not lead to the sudden replacement of older products that do not fulfill the more stringent standards. More interesting from an analytical point of view are the energy-related products that are required to fulfill certain new energy-efficiency criteria. The EPBD establishes certain energy efficiency standards for buildings that can only be achieved by upgrading the insulation of existing buildings or through using better insulation for new buildings. More insulation translates into more demand for insulation products and hence more trade. The objective of this section is to analyze empirically whether we find such effects in the EU. Our analysis is unique in including data on the gaps in the implementation of the directive, an approach that to our knowledge has not been explored in the related literature. This allows us to examine how trade responds based on the implementation performance of importers and exporters. 


\section{A. Data}

As the directive had a transposition deadline of 9 July 2012, we examine pooled data for the time period from 2012 to 2015 (for which the latest data is available).

The data on nominal bilateral import flows and unit values (in euros) are from the UN Comtrade database for four types of insulation products:

i. buildings insulation materials, particularly rock wool (HS 680610),

i. insulating materials and articles (HS 680690),

ii. multiple-walled insulating units of glass (HS 700800), and

iii. glass-fiber insulation products (HS 701939).

These products were chosen as their use helps to lower carbon dioxide emissions and increase the energy efficiency of buildings. All four products contribute to energy savings for space heating, which accounts for the majority of energy consumption in households across all member states, with large shares among most of the colder countries. On average, space heating accounts for about two-thirds of household energy consumption in the EU (Odyssee-Mure 2015).

In addition to the importance of the aforementioned products for the implementation of the EPBD, the products have the advantage of being almost entirely single-use products. In other words, the majority of the imported products will be used for the insulation of buildings. Hence, these products should be suitable for capturing the trade of low-carbon products in response to the EU's introduction of the directive (Vossenaar 2010).2) Finally, insulation is mentioned explicitly in the directive.

Overall, we have data on trade flows for four years spanning from 2012 to 2015 for 28 importing EU countries and 58 exporting countries (including the $28 \mathrm{EU}$ countries). ${ }^{3)}$ Data on the distances between countries, whether the countries share a colonial link, whether they have a common official language, and whether they share a border are from CEPII, and GDP are obtained from the CEPII-CHELEM database

For our analysis, we first estimate the model using the data from Ecofys on the implementation gaps for each member state using pooled ordinary least square (OLS) and Poisson estimators. We follow up by estimating the model by commodity. Finally, we produce a ranking of the countries based on their implementation gaps and use this ranking to assign an implementation score for each country-this provides an alternative indicator showing whether the countries are good or bad implementers.

2) Other goods classified in the HS system that could contribute to the fight against climate change might be used for different purposes. For example, masts, commonly used for wind turbines, can be used for various other purposes.

3) For the analysis, we included the sample of exporters for only those countries with some exports of the relevant products during the period. In other words, we excluded countries that did not export the insulation-related products at all during 2012-2015. Otherwise, the sample would contain a large number of zero trade flows, which are not meaningful, as some countries simply do not produce any of the four types of products included in the sample. 


\section{B. Methodology}

For our empirical analysis, we use the gravity model to analyze the relationship between the trade in energy efficiency-enhancing products and the degree of implementation of the EPBD by individual EU member states. The gravity model, originally proposed by Tinbergen (1962), is an effective and widely used tool for analyzing the determinants of trade. Based on Newton's theory of gravity, It proposes a relationship where the bilateral trade flows between countries are proportional to the size (GDP) of the countries but inversely proportional to the distance between them. Other variables are also commonly included in the model as proxies for historical or cultural proximity. These include variables related to whether the countries share geographical borders, have a common official language, or have colonial links.

The estimated gravity equation takes the form

$$
\begin{aligned}
\operatorname{lnM}_{i j}=a_{0} & +a_{1} \ln \left(g d p_{i}\right)+a_{2} \ln \left(g d p_{j}\right)+a_{3} \ln \left(\text { dist }_{i j}\right)+a_{4}\left(\text { comcol }_{i j}\right)+a_{5}\left(\text { comlang }_{i j}\right)+a_{6}\left(\text { contig }_{i j}\right) \\
& +a_{7}\left(\text { implement }_{i}\right)+a_{8}\left(\text { implementex }_{j}\right)+a_{9}\left(u v_{i}\right)+d_{i}+d_{j}+\epsilon_{i j}
\end{aligned}
$$

where $M_{i j}$ represents the nominal imports of country $i$ from country $j$; gdp $\mathrm{p}_{\mathrm{i}}$ and $\operatorname{gdp}_{\mathrm{j}}$ are the GDP of the importer and exporting countries, respectively; dist $i_{i j}$ is the geographical distance between the capital cities of country $i$ and $j$; comcol $_{i j}$ is a dummy variable that equals 1 if countries $i$ and $j$ have a colonial link and is 0 otherwise; comlang $_{i j}$ is a dummy variable that equals 1 if countries $i$ and $j$ share a similar official language and is 0 otherwise; contig $g_{i j}$ is a dummy variable that equals 1 if countries $i$ and $j$ share a border and is 0 otherwise; implement $_{i}$ is a measure of the level of implementation of the EPBD of the importing EU member state; and implementex in $_{j}$ is a measure of the level of implementation of the EPBD of the exporting EU member state. $d_{i}$ and $d_{j}$ are dummy variables that denote the importing/exporting countries and the years and are included as suggested by Feenstra (2002) to capture country- and year-specific fixed effects and control for unobserved country and time characteristics. $\varepsilon_{i j}$ is the error term.

We include the unit value $(u v)$ of the import trade flow, which is simply the FOB export value divided by the volume. Unit values are regularly used as a proxy for prices in empirical trade studies, e.g., Chen and Juvenal (2016), since prices are not directly observed. Unit values can only be used with highly disaggregated trade data like in our case. The unit value captures difference in import prices across countries. Higher import volumes can reduce the prices of goods due to economies of scale and increased competition. For example, Helble and Aizawa (2016) find such effects in the case of the insulin trade.

Given the fact that our data on implementation based on Ecofys (2015) is limited to one year, we are unable to make full use of the time dimension in our sample. In a first step, 
we therefore run the gravity equation on the pooled set of trade data, including year and country fixed effects.

Our trade data is highly disaggregated and therefore many bilateral trade flows are zero. Santos Silva and Tenreyro (2006) propose using the Poisson pseudo-maximum likelihood (PPML) estimator to address the prominent presence of zeroes and of heteroskedasticity in bilateral trade flow data. However, the statistical software package Stata is unable to find a solution when applying the PPML estimator to our full dataset due to the very high number of zero trade flows. In our full dataset, a large share of the trade flows is zero. This is unsurprising as the production of the building materials is concentrated in a rather small number of countries worldwide.

To reduce the number of zero trade flows, we included only those countries with at least one positive export flow to the EU countries. For example, if Morocco did not export any of the four products to any EU country, it was dropped from the sample. We argue that this assumption is reasonable as zero trade flows should be included to consider the high trade costs between countries that might prohibit trade. However, in our case, since Morocco did not produce any of the materials, it would not export them even if trade costs were zero.

\section{Results}

The estimation results using pooled OLS and Poisson estimators for the period 2012 2015 are shown in Table 2.

The results for the standard gravity equation variables are as expected for both estimation methods. The distance between importers and exporters is negatively associated with trade, while economic size (GDP), having colonial links, a shared border, and a common language is positively associated with trade.

Importantly, the coefficients of the variables representing the implementation gaps of the member states as importers and exporters are negative and significant at either the $5 \%$ or $1 \%$ level. This indicates that a smaller implementation gap is associated with increased trade in insulation-related products during the period. These results are consistent even when carrying out the estimation by product type (Table 3).

The coefficients for the unit values are consistently negative and highly statistically significant in the pooled regression. This suggests that more trade in environmental goods helped to lower the goods' prices. However, we cannot fully rule out the presence of endogeneity in this relationship. Overall, more comprehensive implementation has a positive effect on import volumes and possibly reduces prices. 
Table 2. Estimation results: implementation gaps, 2012 2015

\begin{tabular}{|c|c|c|c|c|}
\hline Variable & $\begin{array}{c}\text { (i) } \\
\text { Pooled OLS }\end{array}$ & $\begin{array}{c}\text { (ii) } \\
\text { Poisson }\end{array}$ & $\begin{array}{c}\text { (iii) } \\
\text { Pooled OLS }\end{array}$ & $\begin{array}{c}\text { (iv) } \\
\text { Poisson }\end{array}$ \\
\hline \multirow[t]{2}{*}{ In GDP importer } & $1.11^{* * *}$ & $1.13 * * *$ & $1.13 * * *$ & $1.12 * * *$ \\
\hline & $(0.03)$ & $(0.03)$ & $(0.03)$ & $(0.04)$ \\
\hline \multirow[t]{2}{*}{ In GDP exporter } & $1.07 * * *$ & $1.09 * * *$ & $1.10 * * *$ & $1.10^{* * *}$ \\
\hline & $(0.04)$ & $(0.04)$ & $(0.03)$ & $(0.04)$ \\
\hline \multirow[t]{2}{*}{ In Distance } & $-1.17 * * *$ & $-1.16^{* * *}$ & $-1.17 * * *$ & $-1.17 * * *$ \\
\hline & $(0.11)$ & $(0.11)$ & $(0.11)$ & $(0.11)$ \\
\hline \multirow[t]{2}{*}{ Common colony } & 0.81 & 0.92 & 0.81 & 0.92 \\
\hline & $(0.62)$ & $(0.69)$ & $(0.63)$ & $(0.68)$ \\
\hline \multirow[t]{2}{*}{ Common language } & 0.40 & $0.55 * *$ & 0.41 & $0.56^{* *}$ \\
\hline & $(0.29)$ & $(0.24)$ & $(0.29)$ & $(0.26)$ \\
\hline \multirow[t]{2}{*}{ Contiguous } & $1.34 * * *$ & $0.72 * * *$ & $1.33 * * *$ & $0.73 * * *$ \\
\hline & $(0.19)$ & $(0.13)$ & $(0.17)$ & $(0.15)$ \\
\hline \multirow[t]{2}{*}{ Implementation gap score (importer) } & $-0.67 * * *$ & $-0.70 * * *$ & & \\
\hline & $(0.11)$ & $(0.10)$ & & \\
\hline \multirow[t]{2}{*}{ Implementation gap score (exporter) } & $-0.35 * * *$ & -0.16 & & \\
\hline & $(0.12)$ & $(0.11)$ & & \\
\hline \multirow[t]{2}{*}{ In Implementation gap score (importer) } & & & $-4.81 * * *$ & $-5.06 * * *$ \\
\hline & & & $(0.84)$ & $(0.75)$ \\
\hline \multirow[t]{2}{*}{ In Implementation gap score (exporter) } & & & $-2.55 * * *$ & -1.17 \\
\hline & & & $(0.88)$ & $(0.83)$ \\
\hline \multirow[t]{2}{*}{ In Unit value } & $-0.26 * * *$ & -0.068 & $-0.26 * * *$ & -0.068 \\
\hline & $(0.04)$ & $(0.08)$ & $(0.04)$ & $(0.08)$ \\
\hline$R$-squared & 0.40 & & 0.40 & \\
\hline Observations & 5,33 & 5,33 & 5,33 & 5,33 \\
\hline
\end{tabular}

(Notes) (i) OLS = ordinary least squares.

(ii) Robust standard errors are in parentheses. Estimated with year fixed effects (not reported). $* * * \mathrm{p}<0.01$, ** $\mathrm{p}<0.05, * \mathrm{p}<0.1$

(Source) Authors.

Table 3 shows the results using the Poisson estimator with imports separated into their four products groups. The implementation gap variables for the importers of the products all show a negative and statistically significant relationship. For the exporters, the coefficients are all negative, but only statistically significant for products HS 700800 and HS 701939. In general, this shows good support for the relationship that a smaller implementation gap is accompanied by increased trade, as seen in Table 2, even at the product level. 
Table 3. Poisson estimation results by product: implementation gaps, 2012 2015

\begin{tabular}{|c|c|c|c|c|}
\hline Variable & $\begin{array}{ll} & \text { (i) } \\
\text { HS } & 680610\end{array}$ & $\begin{array}{cl}\text { (ii) } \\
\text { HS } & 680690\end{array}$ & $\begin{array}{c}\text { (iii) } \\
\text { HS } 700800\end{array}$ & $\begin{array}{ll} & \text { (iv) } \\
\text { HS } & 701939\end{array}$ \\
\hline \multirow[t]{2}{*}{ In GDP importer } & $1.13 * * *$ & $1.15^{* * *}$ & $1.17 * * *$ & $1.16^{* * *}$ \\
\hline & $(0.05)$ & $(0.06)$ & $(0.07)$ & $(0.06)$ \\
\hline \multirow[t]{2}{*}{ In GDP exporter } & $1.09 * * *$ & $1.10^{* * *}$ & $1.11 * * *$ & $1.10^{* * *}$ \\
\hline & $(0.06)$ & $(0.05)$ & $(0.04)$ & $(0.04)$ \\
\hline \multirow[t]{2}{*}{ In Distance } & $-1.59 * * *$ & $-1.04 * * *$ & $-0.96^{* * *}$ & $-0.87 * * *$ \\
\hline & $(0.20)$ & $(0.15)$ & $(0.18)$ & $(0.16)$ \\
\hline \multirow[t]{2}{*}{ Common colony } & $1.80^{* *}$ & $2.33^{* * *}$ & 1.29 & $-1.52 * *$ \\
\hline & $(0.83)$ & $(0.67)$ & $(0.93)$ & $(0.76)$ \\
\hline \multirow[t]{2}{*}{ Common language } & $0.74 *$ & $1.11 * * *$ & 0.56 & 0.55 \\
\hline & $(0.44)$ & $(0.38)$ & $(0.44)$ & $(0.37)$ \\
\hline \multirow[t]{2}{*}{ Contiguous } & $1.03 * * *$ & 0.24 & $1.72 * * *$ & $0.69^{* * *}$ \\
\hline & $(0.26)$ & $(0.21)$ & $(0.27)$ & $(0.23)$ \\
\hline \multirow[t]{2}{*}{ Implementation gap score (importer) } & $-0.64 * * *$ & $-0.46^{* * *}$ & $-0.96 * * *$ & $-0.89 * * *$ \\
\hline & $(0.16)$ & $(0.101)$ & $(0.15)$ & $(0.19)$ \\
\hline \multirow[t]{2}{*}{ Implementation gap score (exporter) } & 0.098 & -0.0403 & -0.094 & $-0.61 * * *$ \\
\hline & $(0.18)$ & $(0.14)$ & $(0.16)$ & $(0.19)$ \\
\hline \multirow[t]{2}{*}{ In Unit value } & -0.16 & $0.16^{*}$ & -0.08 & $-0.29 * *$ \\
\hline & $(0.17)$ & $(0.09)$ & $(0.08)$ & $(0.12)$ \\
\hline Observations & 1,407 & 1,328 & 1,205 & 1,392 \\
\hline
\end{tabular}

(Note) Robust standard errors are in parentheses. Estimated using the Poisson estimator with country and year fixed effects (not reported). ${ }^{* * *} \mathrm{p}<0.01, * * \mathrm{p}<0.05, * \mathrm{p}<0.1$

(Source) Authors.

The coefficients of the unit values are negative in all four regressions and statistically significant for product HS 680690 as well as HS 701939. Without having detailed information about the structure of the industry, it is difficult to know why we observe a significant effect for some products but not for others.

Table 4 provides a robustness check by including variables of the implementation scores based on rankings of the member states by their degree of implementation. Higher scores indicate higher levels of implementation, and, as such, indicate whether a member state is a "good" or "bad" implementer. The estimation results show positive and highly significant coefficients for the importer scores and positive and mostly significant coefficients for the exporter scores. Meanwhile, Table 5 estimates the data by product and again indicates positive and significant relationships between importer implementation scores and imports for each of the products. The unit value coefficients for both tables are also consistent with the previous results, showing, generally, that the unit values as trade volume increases. 
These findings corroborate the results in Tables 2 and 3 and strongly suggest that a high level of implementation of the EPBD as a regional policy is associated with increased trade in low-carbon or energy efficiency-enhancing products. This has important implications for the interaction between regional policies for promoting energy efficiency and the uptake of environmental goods and low-carbon products.

Table 4. Estimation results: implementation scores based on rankings, 2012 2015

\begin{tabular}{|c|c|c|c|c|}
\hline Variable & $\begin{array}{c}\text { (i) } \\
\text { Pooled OLS }\end{array}$ & $\begin{array}{c}\text { (ii) } \\
\text { Poisson }\end{array}$ & $\begin{array}{c}\text { (iii) } \\
\text { Pooled OLS }\end{array}$ & $\begin{array}{c}\text { (iv) } \\
\text { Poisson }\end{array}$ \\
\hline In GDP importer & $\begin{array}{c}1.10^{* * *} \\
(0.02)\end{array}$ & $\begin{array}{c}1.13^{* * *} \\
(0.03)\end{array}$ & $\begin{array}{c}1.15^{* * *} \\
(0.04)\end{array}$ & $\begin{array}{c}1.16^{* * *} \\
(0.05)\end{array}$ \\
\hline In GDP exporter & $\begin{array}{c}1.07 * * * \\
(0.03)\end{array}$ & $\begin{array}{c}1.08 * * * \\
(0.04)\end{array}$ & $\begin{array}{c}1.14^{* * * *} \\
(0.05)\end{array}$ & $\begin{array}{c}1.15^{* * *} \\
(0.03)\end{array}$ \\
\hline In Distance & $\begin{array}{c}-1.156^{* * *} \\
(0.110)\end{array}$ & $\begin{array}{c}-1.150^{* * *} \\
(0.106)\end{array}$ & $\begin{array}{c}-1.167 * * * \\
(0.123)\end{array}$ & $\begin{array}{c}-1.077 * * * \\
(0.120)\end{array}$ \\
\hline Common colony & $\begin{array}{c}1.015 \\
(0.623)\end{array}$ & $\begin{array}{l}1.301^{* *} \\
(0.639)\end{array}$ & $\begin{array}{l}1.328 * * \\
(0.648)\end{array}$ & $\begin{array}{l}1.237 * * \\
(0.613)\end{array}$ \\
\hline Common language & $\begin{array}{c}0.394 \\
(0.280)\end{array}$ & $\begin{array}{c}0.493 * * \\
(0.239)\end{array}$ & $\begin{array}{c}0.453 \\
(0.315)\end{array}$ & $\begin{array}{l}0.510^{* *} \\
(0.255)\end{array}$ \\
\hline Contiguous & $\begin{array}{c}1.279 * * * \\
(0.201)\end{array}$ & $\begin{array}{c}0.730 * * * \\
(0.167)\end{array}$ & $\begin{array}{c}1.243 * * * \\
(0.230)\end{array}$ & $\begin{array}{c}0.746 * * * \\
(0.180)\end{array}$ \\
\hline In Implementation rank score (importer) & & & $\begin{array}{c}8.328 * * * \\
(1.439)\end{array}$ & $\begin{array}{c}7.610^{* * *} \\
(1.331)\end{array}$ \\
\hline In Implementation rank score (exporter) & & & $\begin{array}{c}4.733^{* * * *} \\
(1.590)\end{array}$ & $\begin{array}{c}2.755^{* *} \\
(1.383)\end{array}$ \\
\hline Implementation rank score (importer) & $\begin{array}{l}0.218^{* * *} \\
(0.0374)\end{array}$ & $\begin{array}{l}0.218^{* * *} \\
(0.0348)\end{array}$ & & \\
\hline Implementation rank score (exporter) & $\begin{array}{l}0.103 * * * \\
(0.0341)\end{array}$ & $\begin{array}{c}0.0476 \\
(0.0325)\end{array}$ & & \\
\hline In Unit value & $\begin{array}{c}-0.317 * * * \\
(0.046)\end{array}$ & $\begin{array}{r}-0.0963 \\
(0.080)\end{array}$ & $\begin{array}{c}-0.293 * * * \\
(0.051)\end{array}$ & $\begin{array}{c}-0.224 * * * \\
(0.078)\end{array}$ \\
\hline$R$-squared & 0.428 & & 0.423 & \\
\hline Observations & 5,085 & 5,085 & 4,035 & 4,035 \\
\hline
\end{tabular}

(Notes) (i) OLS = ordinary least squares.

(ii) Robust standard errors are in parentheses. Estimated with year fixed effects (not reported). $* * * \mathrm{p}<0.01, * * \mathrm{p}<0.05, * \mathrm{p}<0.1$

(Source) Authors. 
Table 5. Poisson estimation results by product: implementation scores based on rankings, 2012 2015

\begin{tabular}{|c|c|c|c|c|}
\hline Variable & $\begin{array}{ll} & \text { (i) } \\
\text { HS } & 680610 \\
\end{array}$ & $\begin{array}{cl} & \text { (ii) } \\
\text { HS } & 680690 \\
\end{array}$ & $\begin{array}{cl}\text { (iii) } \\
\text { HS } & 700800 \\
\end{array}$ & $\begin{array}{l}\text { (iv) } \\
\text { HS } 701939\end{array}$ \\
\hline \multirow[t]{2}{*}{ In GDP importer } & $1.15 * * *$ & $1.16^{* * *}$ & $1.14 * * *$ & $1.18 * * *$ \\
\hline & $(0.05)$ & $(0.06)$ & $(0.03)$ & $(0.06)$ \\
\hline \multirow[t]{2}{*}{ In GDP exporter } & $1.03 * * *$ & $1.01 * * *$ & $1.03 * * *$ & $1.04 * * *$ \\
\hline & $(0.03)$ & $(0.02)$ & $(0.03)$ & $(0.03)$ \\
\hline \multirow[t]{2}{*}{ In Distance } & $-1.360 * * *$ & $-1.100 * * *$ & $-0.954 * * *$ & $-0.937 * * *$ \\
\hline & $(0.165)$ & $(0.152)$ & $(0.155)$ & $(0.169)$ \\
\hline \multirow[t]{2}{*}{ Common colony } & $2.186^{* * *}$ & $2.890 * * *$ & 1.148 & -1.052 \\
\hline & $(0.758)$ & $(0.667)$ & $(0.915)$ & $(0.758)$ \\
\hline \multirow[t]{2}{*}{ Common language } & 0.684 & $1.295^{* * *}$ & 0.526 & 0.289 \\
\hline & $(0.435)$ & $(0.372)$ & $(0.396)$ & $(0.381)$ \\
\hline \multirow[t]{2}{*}{ Contiguous } & $1.041 * * *$ & 0.0675 & $1.735^{* * *}$ & $0.853 * * *$ \\
\hline & $(0.255)$ & $(0.217)$ & $(0.288)$ & $(0.276)$ \\
\hline \multirow[t]{2}{*}{ Implementation rank score (importer) } & $0.195 * * *$ & $0.129 * * *$ & $0.297 * * *$ & $0.281 * * *$ \\
\hline & $(0.0551)$ & $(0.0307)$ & $(0.0514)$ & $(0.0568)$ \\
\hline \multirow[t]{2}{*}{ Implementation rank score (exporter) } & -0.0455 & 0.0116 & 0.0365 & $0.192 * * *$ \\
\hline & $(0.0429)$ & $(0.0388)$ & $(0.0463)$ & $(0.0549)$ \\
\hline \multirow[t]{2}{*}{ In Unit value } & $-0.262 *$ & $0.181 * *$ & -0.113 & $-0.279 * *$ \\
\hline & $(0.138)$ & $(0.0891)$ & $(0.0693)$ & $(0.118)$ \\
\hline Observations & 1,323 & 1,259 & 1,141 & 1,362 \\
\hline
\end{tabular}

(Notes) Robust standard errors are in parentheses. Estimated using the Poisson estimator with country and year fixed effects (not reported). *** $\mathrm{p}<0.01, * * \mathrm{p}<0.05, * \mathrm{p}<0.1$

(Source) Authors.

\section{Lessons for Asia and the Pacific}

Most countries in Asia and the Pacific have signed and ratified the 2015 Paris Agreement, thereby submitting their intended nationally determined contributions (INDCs) to fight climate change. Table 6 gives an overview of the INDCs of selected countries in Asia. Most national emissions reduction targets are considerable, especially for developing countries with currently high economic growth rates, such as the Philippines or Vietnam. Given the expected continued economic growth of the region, substantive efforts will be needed to achieve these targets, and these efforts should work on the same three fronts as the EU: (i) a reduction of greenhouse gas emissions, (ii) an increase in the share of renewable energy, and (iii) improvements in energy efficiency. 
Table 6. Intended national determined contributions for selected asian countries

\begin{tabular}{clll}
\hline Country & \multicolumn{1}{c}{ INDC Target } & Country & \multicolumn{1}{c}{ INDC Target } \\
\hline $\begin{array}{c}\text { Brunei } \\
\text { Darussalam }\end{array}$ & $\begin{array}{l}\text { Reduce total energy consumption by } 63 \% \\
\text { by } 2035\end{array}$ & Malaysia & $\begin{array}{l}35 \% \text { in emission intensity of base year } \\
\text { GDP and conditional } 45 \% \text { (ref. 2005) }\end{array}$ \\
\hline Cambodia & Conditional 27\% by 2030 (ref. BAU) & Philippines & Conditional 70\% by 2030 (ref. BAU) \\
\hline $\begin{array}{c}\text { People's } \\
\text { Republic } \\
\text { of China }\end{array}$ & $\begin{array}{l}60 \%-65 \% \text { per unit of GDP by 2030 } \\
\text { (ref 2005) }\end{array}$ & $\begin{array}{l}\text { Republic } \\
\text { of Korea }\end{array}$ & $37 \%$ by 2030 (ref. BAU) \\
\hline India & $\begin{array}{l}\text { Conditional 33\%-35\% per unit of GDP by } \\
2030 \text { (ref. 2005) }\end{array}$ & Singapore & $36 \%$ by 2030 (ref. 2005) \\
\hline Indonesia & $29 \%$ and conditional 41\% by 2030 (ref. BAU) & Thailand & $20 \%$ and conditional 25\% by 2030 (ref. BAU) \\
\hline Japan & $26 \%$ by 2030 (ref. 2013) & Vietnam & $8 \%$ and conditional 25\% by 2030 (ref. BAU) \\
\hline
\end{tabular}

(Note) BAU = business as usual, GDP = gross domestic product, INDC = intended nationally determined contribution. (Source) Authors, based on country submissions to the UNFCCC (2015).

Our paper has focused on measures to improve the energy efficiency of buildings. In Asia, this area holds considerable potential for energy savings. Due to strong economic growth and rapid urbanization, the building stock has increased dramatically in the region. For example, Beijing's physical size quadrupled from 2000 to 2009 (Jacobsen 2015). Even in economies with slower growth, additions to the building stock have been impressive. For example, in Bangkok, a third of currently existing multi-story buildings were built within the last decade (Bangkok Post 2017).

As economic growth is forecasted to continue in the near future (ADB 2017), combined with increasing populations, rising incomes, and urbanization, the building stock in Asia is expected to rapidly expand in the coming decades. In the case of the People's Republic of China (PRC), experts estimate that $40 \%$ of the country's building stock in 2030 has yet to be built (Cheng and Tong 2017).

The heating and cooling of buildings consume a large share of energy in every country in the region. As such, large potential energy savings exist in the buildings sector throughout Asia. Yet, few developing countries in the region have introduced technical regulations for buildings. The PRC issued the first building energy code in 1986 for residential buildings in the northern part of the country requiring a reduction in space heating energy consumption. In 2006, the Chinese government introduced a green building labeling system.

Energy codes can help to increase energy efficiency and lower greenhouse gas emissions. At the same time, the transition to more energy-efficient buildings comes at a cost. The corresponding compliance costs need to be carefully considered and justified to successfully achieve energy efficiency as a central part of building construction. Coordinated legislation like the EU's Performance of Buildings Directive would help inform and guide new urban constructions and lock in energy savings while reducing energy consumption in existing 
buildings (IEA 2014).

As this paper has shown, the implementation of technical regulations on energy efficiency will also have direct effects on trade. We found that well-coordinated regulation and more rapid implementation can lead to an increase in the trade and diffusion of low-carbon technologies. However, technical regulation can also become a barrier to trade if the latter is not harmonized with international standards, thus imposing additional costs to producers.

Several developing countries in Asia are currently considering introducing energy codes for buildings. While this new legislation has the potential to improve energy efficiency, legislators need to ensure that energy codes do not unnecessarily impede trade. In the best case, developing countries in Asia will follow the example of the EU and agree on common standards. Obviously, the EU has a different level of institutional integration compared to Asia (Helble 2016). However, the Association of Southeast Asian Nations (ASEAN) could be a trusted authority for achieving establishing regional common standards. Mandatory regulations and certification schemes could be coordinated through ASEAN's Energy Management Scheme or through other energy management schemes, such as ISO 50001 (IEA 2014). Such standards would have the added benefits of raising awareness and acceptance in the region.

However, having common standards will not be enough. As the case of the EU illustrates, the implementation of existing legislation can be difficult. In developing countries, political commitment and public support are some of the main challenges in adopting energy efficiency legislation (Liu Mayer and Hogan 2010). Developing countries need to find ways to ensure full enforcement and compliance with the introduced regulations.

In the best case, common technical regulations and full implementation would result in a boost in trade of environmental goods in the region. Increased demand and trade of environmental goods would most likely also spur innovation in the area. Eventually, Asia could further improve its competitiveness in the sector relative to other regions. A well-coordinated approach to reducing energy consumption could thus become a catalyst for a win-win scenario-the introduction and implementation of new legislation would contribute to the fight against climate change as well as increase trade, innovation, and competitiveness in the region.

\section{Conclusion}

In this paper, we studied the trade effect of a directive that has been adopted at the European level and transposed into national law by the EU member states. The member states differed in their effective implementation of the law-thus, we have a case of a policy change applied to a group of countries with implementation that varies across countries. Our research objective was to study how different degrees of implementation of new environmental regulations affect 
trade. Analysis of our data shows that trade in related products increased, suggesting that the EPBD indeed had a profound impact on the EU market for energy-consuming and energy-related products.

The EPBD provides a prime example of regional cooperation for the promotion of low-carbon technologies based on non-market instruments. The directive started as a reaction to the European Strategy for Energy and Climate Change adopted in 2008, established the 20-20-20 targets, and is mainly intended to pull and push the market toward more energy-efficient outcomes by using non-market instruments.

Our empirical analysis highlights the potential for regional policies to promote trade in low-carbon and energy-efficient products. The findings show that trade in the examined products was positively associated with strong implementation of the EPBD following its introduction and transposition for EU member states. This has important implications for the relationship between trade and regional policies for energy-efficient goods.

While Asia continues on its path of increased economic prosperity, the region has committed to making significant contributions to lower global greenhouse gas emissions in line with the framework of the Paris Agreement. Stringent regulations to lower the energy consumption of buildings can significantly increase their energy efficiency. As the region is quickly expanding its building stock, it should be a priority to introduce such regulations.

When introducing new legislation, Asian countries should consider the impact on international trade. Harmonized or coordinated technical regulations across countries have the potential to boost trade among the Asian countries and therefore foster regional economic integration. At the same time, common regulation would spur competition, possibly leading to faster technological progress in the field. Finally, it could help create economies of scale. Since many products in Asia are produced in supply chains, having a standardized product for all markets would generate enormous economies of scale. Eventually, the consumer would benefit from better and cheaper products. In contrast, unilateral attempts that are not aligned with international standards will impede trade and result in higher costs as firms are unable to reap the economies of scale. Furthermore, companies might be less exposed to foreign competition and less promoted to innovate.

Beyond the economic benefits, having harmonized technical regulations across Asia would increase the awareness that joint efforts in the fight against climate change are more effective than individual action by countries. This growing awareness might trigger additional joint efforts by Asian countries to become greener.

Overall, collaborating on technical regulations in the area of environmental protection is an enormous, yet often underestimated, chance to transform Asia into a more competitive, prosperous, and greener region. 


\section{References}

Asian Development Bank (ADB) (2017). Asian Development Outlook 2017: Transcending the Middle-Income Challenge, ADB: Manila.

Bangkok Post (2017). "5,000 Potential 'Grenfell Towers' in City, Experts Warn.” 21 June.

Chen, N., and L. Juvenal (2016). "quality, trade, and exchange rate pass-through.” Journal of International Economics 100, 61-80.

Cheng, V. S., and J. C. Tong (2017). Building sustainability in East Asia: Policy, design and people, Wiley.

Cole, M. A., and R. J. R. Elliott (2003). "do environmental regulations influence trade patterns? Testing old and new trade theories." World Economy 26, no. 8, 1163-1186.

Cole, M. A., R. J. R. Elliott, and T. Okubo (2014). "international environmental outsourcing." Review of World Economics 4, 1-26.

Costantini, V., and M. Mazzanti (2012). "on the green and innovative side of trade competitiveness? The impact of environmental policies and innovation on EU exports." Research Policy 41,132-153.

Dechezleprêtre, A, and M. Sato (2014). "The Impact of Environmental Regulations on Competitiveness." Grantham Research Institute on Climate Change and the Environment Policy Brief. http://www.lse.ac.u k/GranthamInstitute/wp-content/uploads/2014/11/Impacts_of_Environmental_Regulations.pdf

Ecofys (2015). Assessment of Cost Optimal Calculations in the Context of the EPBD: Final Report, Cologne, Germany: Ecofys.

European Union (EU) (2009a). Directive 2009/29/EC of the European Parliament and of the Council of 23 April 2009 Amending Directive 2003/87/EC so as to Improve and Extend the Greenhouse Gas Emission Allowance Trading Scheme of the Community. http://eur lex.europa.eu/legal content/EN/ TXT/?uri=CELEX:32009L0029

EU (2009b). Directive 2009/125/EC of the European Parliament and of the Council of 21 October 2009 Establishing a Framework for the Setting of Ecodesign Requirements for Energy-related Products. http://eur lex.europa.eu/legal content/EN/ALL/?uri=CELEX:32009L0125

EU (2010). Directive 2010/31/EU of the European Parliament and of the Council of 19 May 2010 on the Energy Performance of Buildings. http://eurlex.europa.eu/LexUriServ/LexUriServ.do?uri=OJ:L:20 10:153:00

EU (2012). Directive 2012/27/EU of the European Parliament and of the Council of 25 October 2012 on Energy Efficiency, Amending Directives 2009/125/EC and 2010/30/EU and Repealing Directives 2004/8/EC and 2006/32/EC. http://eur lex.europa.eu/LexUriServ/LexUriServ.do?uri=CELEX:32012L0 027:EN:PDF

European Parliament (2002). Directive 2002/91/EC of the European Parliament and of the Council of 16 December 2002 on the Energy Performance of Buildings. http://eur-lex.europa.eu/legal-content/EN/ TXT/?uri=celex\%3A32002L0091

Feenstra, R. (2002). "border effects and the gravity equation: Consistent methods for estimation." Scottish Journal of Political Economy 49, no. 5, 491-506.

Grajek, M. (2004). Diffusion of ISO 9000 Standards and International Trade, Discussion Paper SPII 2004-16. Berlin: Wissenschaftszentrum. 
Han, L., B. Han, X. Shi, B. Su, X. Lv, and X. Lei (2018). "Energy efficiency convergence across countries in the context of China's Belt and Road initiative." Applied Energy 213, 112-122.

Helble, M. (2016). "Low Carbon Energy Transition in EU: Lessons from Economic, Institutional and Management Approaches.” In Investing in Low Carbon Energy Systems, eds. K. Kalirajan, V. Anbumozhi, F. Kimura, and X. Yao. Springer.

Helble, M., and T. Aizawa (2016). "international trade and determinants of price differentials of insulin medicine." Health Policy and Planning 32, 1, 1-10.

International Energy Agency (2014). Regional energy efficiency policy recommendations: Southeast asia region, Paris: International Energy Agency.

Jacobson, M. Z., S. V. Nghiem, A. Sorichetta, and N. Whitney (2015). "Ring of impact from the Mega-urbanization of Beijing between 2000 and 2009." Journal of Geophysical Research: Atmosphere $120,5740-5756$.

Jaffe, A. B., and K. Palmer (1997). "environmental regulation and innovation: A panel data study." Review of Economics and Statistics 79, no. 4, 610-619.

Janicke, M., M. Binder, and H. Monch (1997). "Dirty industries: Patterns of change in industrial countries." Environmental and Resource Economics 9,467-491.

Jug, J., and D. Mirza (2005). "Environmental regulations in gravity equations: Evidence from europe." The World Economy 28, no. 11, 1591-1615.

Leung, E., and P. Mar (2013). Energy efficiency in buildings in Asia: Realizing the untapped opportunity, Fung Global Institute Working Paper. Fung Global Institute.

Liu, F., A. S. Meyer, and J. F. Hogan (2010). Mainstreaming building energy efficiency codes in developing countries: Global experiences from early adopters, World Bank Working Paper No. 204. Washington, DC: World Bank.

Odyssee-Mure (2015). Energy Efficiency Trends and Policies in the Household and Tertiary Sectors. http://www.odyssee-mure.eu/publications/br/energy-efficiency-in-buildings.html

Porter, M. E., and C. van der Linde (1995). "toward a new conception of the environment-competitiveness relationship." Journal of Economic Perspectives 9, no. 4, 97-118.

Sammer, K., and R. Wustenhagen (2006). "The influence of eco-labelling on consumer behaviour-results of a discrete choice analysis for washing machines." Business Strategy and the Environment 15, 185-199.

Shen, J., and T. Saijo (2009). "Does an energy efficiency label alter consumers' purchasing decisions? A latent class approach based on a stated choice experiment in shanghai." Journal of Environmental Management 90, no. 11, 3561-3573.

Silva, S., and S. Tenreyro (2006). "The log of gravity." Review of Economics and Statistics 88, no. 4, 641-658.

Tinbergen, J. (1962). Shaping the world economy: Suggestions for an international economic policy. New York: The Twentieth Century Fund.

United Nations Environmental Programme and World Trade Organization (2009). Trade and Climate Change. Geneva.

United Nations Framework Convention on Climate Change (UNFCCC) (2015). Submission by Latvia 
and the European Commission on Behalf of the European Union and Its Member States. 6 March. http://www4.unfccc.int/Submissions/INDC/Published\%20Documents/Latvia/1/LV-03-06-EU\%20IND C.pdf

United States Energy Information Administration (2015). Chinese Policies Aim to Increase Energy Efficiency in Buildings. October 26. https:/www.eia.gov/todayinenergy/detail.php?id=23492

Vossenaar, R. (2010). Climate-related Single-use Environmental Goods. ICTSD Issue Paper No. 13. Geneva, Switzerland: International Centre for Trade and Sustainable Development.

Wang, Z., B. Zhang, and H. Zen (2016). "The effect of environmental regulation on external trade: Empirical evidences from chinese economy." Journal of Cleaner Production 114, 55-61. 